\title{
Modelling surface runoff and soil erosion for Yen Bai Province, Vietnam, using the Soil and Water Assessment Tool (SWAT)
}

\author{
Mô Hình Hóa Nước Chảy Mặt và Xói Mòn Đất cho Tỉnh Yên Bái, Việt Nam Sủ \\ Dụng Mô Hìn SWAT \\ Research article
}

Nguyen Hong Quang ${ }^{*}$; Le Thi Thu Hang ${ }^{1}$; Pham Thi Thanh Nga ${ }^{1}$; Martin Kappas ${ }^{2}$

${ }^{I}$ Dept. of Satellite Image Processing and Informative Integration, Vietnam National Satellite Center (VNSC), Vietnam Academy of Science and Technology (VAST), Hanoi, Vietnam; ${ }^{2}$ Dept. of Cartography, GIS \& Remote Sensing, GeorgAugust-Universität Göttingen, Göttingen, Germany

\begin{abstract}
Applications of the Soil and Water Assessment Tool (SWAT) are common. However, few attempts have focused on the tropics like in the Yen Bai province, Vietnam. Annual water-induced soil erosion (WSE) rates and surface runoff (SR) were estimated. The Nam Kim and Ngoi Hut watersheds were calibrated with accepted agreement between simulated and observed discharge. Correlations between precipitation, land covers, surface runoff and WSE were indicated. Although the estimated average WSE $4.1 \mathrm{t} \mathrm{ha}^{-1}$ year $^{-1}\left(\mathrm{t} \mathrm{ha}^{-1} \mathrm{y}^{-1}\right)$ was moderate, some steep-bare areas were suffering serious soil loss of $26 \mathrm{t} \mathrm{ha}^{-1} \mathrm{y}^{-1}$ and $15 \%$ of the province was calculated at the rate of $8.5 \mathrm{tha}^{-1} \mathrm{y}^{-1}$. We found that the changes in WSE significantly correlated with land use changes. As calibrated SR matched closely with the measured data, we recommend SWAT applications for long-term soil erosion assessments in the tropics.
\end{abstract}

\begin{abstract}
Nhũng ứng dụng của mô hình công cu đánh giá đất và nước (SWAT) đã được sử dụng phổ biến. Tuy nhiên có rất ít nghiên cưu tập trung vào khu vực nhiệt đới nhu tỉnh Yên Bái của Việt Nam. Trong nghiên cứu này, giá trị trung bình năm (2001-2012) nuoóc chảy bề mặt (NCM) và xói mòn đất do nước (XM) đã được đánh giá trên co sở mô hình SWAT. Các thông số thủy văn của hai lưu vục sông là Nậm Kim và Ngòi Hút được tính toán và kiểm nghiệm với sụ trùng hợp tuoong đối tốt giũ̃a kết quả mô hình và số liệu thực đo. Mối liên hệ giữa lương mưa, phủ bề mặt, NCM và XM cũng được phân tích và trình bầy chi tiết. Mặc dù giá trị XM năm được ước luợng ở mức trung bình cho toàn Tỉnh (4,1 tấn/ha/năm) nhung ở một số khu vưc nơi có độ dốc lớn và phủ mặt ít lại có lượng XM năm ở mức cao, 26 tấn/ha/năm và 15\% tổng diện tích của Tỉnh có giá trị XM là 8,5 tấn/ha/năn. Kết quả nghiên cứu cho thấy sụ liên hệ mật thiết giữa sự thay đổi phủ mặt tới giá trị XM. Trên cơ sở kết quả kiểm nghiệm mô hình khả quan, chúng tôi đề xuất sủ dụng mồ hình SWAT để đánh giá XM trong thời gian dài cho vùng nhiệt đới.
\end{abstract}

Keywords: GIS and remote sensing, hydrological modelling, surface runoff, SWAT, Yen Bai, water-induced erosion

\section{Introduction}

Soil denudation intensity is one of the most favoured topics (Ananda and Herath, 2003) in whole soil erosion and water-induced soil erosion (WSE) (Lopez-Vicente et al., 2013), in particular. The consequences of surface runoff (SR) and soil erosion increase the risk of declining land availability (Dercon et al., 2012) and downstream water quality (Arnhold et al., 2014). Therefore, food security and sustainable development are the main problems in the reduced availability of land per capita countries (Dercon et al., 2012) such as in Vietnam with $2542 \mathrm{~m}^{2}$ per capita in 1930 and $437 \mathrm{~m}^{2}$ per capita in 2011 (VEM, 2012). However, land cover change and unsustainable agricultural practices in recent decades appear to be the main impact on land degradation (Baja et al., 2009; Bakimchandra, 2011). This has been estimated increasingly in recent decades and 
is due to inappropriate agri-cultural practices and social development. Since the 1960s WSE has been studied by various approaches (Evans, 2005). However, only a few studies have focused on the tropics. Reversely, WSE presents the main threat to agriculture in the Yen Bai province of Vietnam, where most people's livelihoods are based on cultivation.

The linkage between SR, WSE amplification, intensive land uses and deforestation has been analysed by various scientists, for example David et al. (2014), and Lopez-Vicente et al. (2013). Since the vegetative cover has been reduced, the soil protection index (SPI-which is a function of land use and land cover (LULC) and Normalized Difference Vegetation Index) has been decreased (Bakimchandra, 2011) or the soil has become less resistant to the erosive force of rain drops and runoff. These result in increasing run off, lower infiltration and eventually soil erosion exaggeration (Andrade et al., 2010). Other studies have focused on impacts of climate change on WSE intensity by increases of annual rainfall, temperature and extreme events (De Munck et al., 2008). However, Mukundan et al. (2013) found that soil erosion and sediment yield (SY) appeared to decrease due to the increase in soil moisture deficit and evapotranspiration. We hypothesized that the rates of soil erosion and sediment transport in Yen Bai would rise mainly due to the decline in vegetative cover.

Water-induced soil erosion assessments by modelling at hill-slope or larger scales have been conducted by many scientists e.g. Gumiere et al. (2011), and Routschek et al. (2014). The SWAT model is known worldwide and there are also many works using the SWAT model to investigate soil erosion by water, or to examine the precision of the model such as the studies of Zhang et al. (2008). Conversely, there have been only a few attempts which have tested the abilities of the SWAT model to the tropical regions. Although the SWAT was developed for dry areas, the algorithms inside the SWAT are able to be implemented in tropical regions and this was proven by the studies of Tibebe (2011) and Fukunaga et al. (2015). After considering the model's requirements, accuracy and outputs, the SWAT was considered suitable and selected for the long-term soil erosion assessment of this study. We took advantages of GIS and remote sensing techniques for the aim of WSE assessment.

The SWAT model showed its ability to generate river discharge matching closely with observed data. Unfortunately, daily measured SY was not available for model validation but the simulated WSE was compared with data from an existing map. The results also revealed the capacity of the model's application for the tropics with reliable outputs.

\section{Study site}

The study site is located within the Yen Bai province of Vietnam (Fig. 1), which is located in north-western Vietnam. The central coordinates that indicate the locality of the watershed are $104^{\circ} 30^{\prime} 9.0^{\prime \prime} \mathrm{E}$ and $21^{\circ} 35^{\prime} 26.7^{\prime \prime} \mathrm{N}$. The area is $6883.5 \mathrm{~km}^{2}$, with the mean elevation of 902 meters above the Bien Dong Sea level. Although the soil erosion rate of Yen Bai is not seen as the highest within the north of Vietnam, the region was chosen as a study area for this research project because of several dominant aspects that were taken into account, such as the typical climatic conditions, representative morphological characteristics, availability of data and the projected upward trend of WSE. Hydrologically, the province is in the three river basins of Da, Hong and Chay.

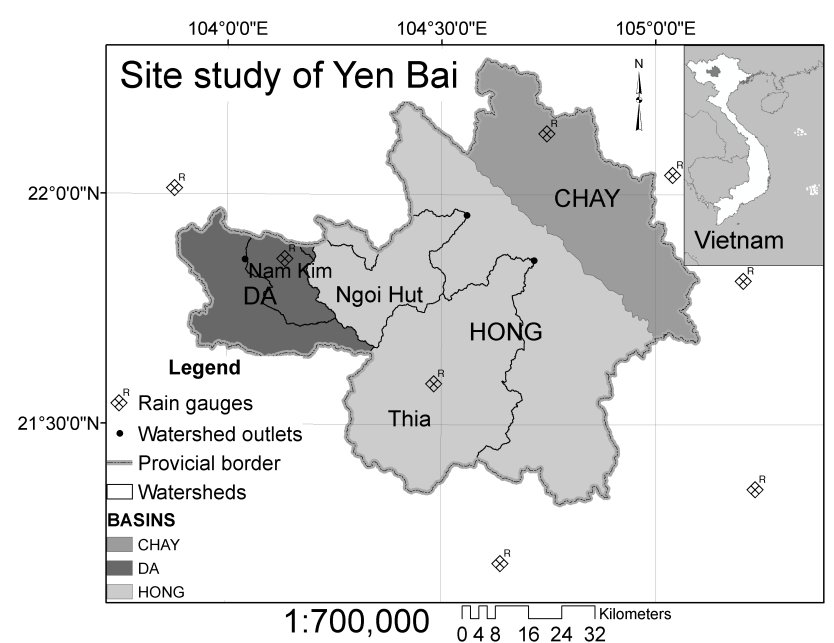

Figure 1. Yen Bai province and 3 watersheds chosen for model calibration and validation

The site has an annual average precipitation (no snow) of $1,638 \mathrm{~mm}$ and the rainfall covers mostly 85 percentage of the total value just in the rainy season from May to September (based on our acquired rainfall data from the 9 rain gauges). Additionally, the terrain of the study area is partitioned by dense stream networks and the average slope gradient was estimated to be 24.4 degrees. Morphologically, the site is considered as an erosive area.

\section{Materials and methods}

\subsection{Modified soil loss equation}

Soil erosion and SY are calculated for each hydrologic response unit (HRU) with the Modified Universal Soil Loss Equation (MUSLE) (Williams, 1975). Whilst within the Universal Soil Loss Equation (USLE) (Wischmeier and Smith, 1965, 1978) precipitation is used as an indicatory force of erosive energy, MUSLE however employs the amount of runoff to estimate erosion and SY (Neitsch et al., 2009). Soil loss is estimated by means of the following equation (Williams, 1995):

$$
\begin{aligned}
& \text { sed }=11.8 \cdot\left(Q_{\mathrm{surf}} \cdot q_{\mathrm{peak}} \cdot \text { area }_{\mathrm{hru}}\right)^{0.56} . \\
& K_{\mathrm{USLE}} \cdot C_{\mathrm{USLE}} \cdot P_{\mathrm{USLE}} \cdot L S_{\mathrm{USLE}} \cdot C F R G
\end{aligned}
$$

Where, sed refers to the SY on any given day ( $\mathrm{t}), Q_{\text {surf }}$ is the volume of surface runoff $\left(\mathrm{mm} \mathrm{ha}^{-1}\right), q_{\text {peak }}$ is the peak runoff rate $\left(\mathrm{m}^{3} \mathrm{~s}^{-1}\right)$, are $_{\mathrm{hru}}$ is the area of the HRU (ha). $K_{\mathrm{USLE}}, C_{\mathrm{USLE}}, P_{\mathrm{USLE}}$ and $L S_{\mathrm{USLE}}$ are the USLE soil erodibility factor, cover and management factor, support practice factor and topographic factor, respectively. The $C F R G$ indicates the coarse fragment factor of the soil. The details of the above components of the equation 1 are presented in the literature of Wischmeier and Smith (1978), Arnold and Williams (1995). 


\subsection{SCS-Curve Number method}

The surface runoff can be estimated by one of the following two provided methods. These include the SCS-CN (Soil Conservation Service-Curve Number) method (USDASCS, 1972) and the Green-Ampt infiltration method (Green and Ampt, 1911). The CN is broadly employed and estimated based on the area's hydrologic soil group, land use, treatment and hydrologic condition. The $\mathrm{CN}$ range is from 30 to 100; lower values indicate low runoff potential while larger numbers show higher runoff potential. The higher $\mathrm{CN}$ values indicate the greater ability of infiltration (USDA-SCS, 1986). The direct runoff from a rainfall event in a particular area is determined efficiently using $\mathrm{CN}$.

In this study, the former approach (USDA-SCS, 1972) has been used. The run-off value can be calculated as:

$Q_{\text {surf }}=\frac{\left(R_{\mathrm{day}}-I_{\mathrm{a}}\right)^{2}}{\left(R_{\mathrm{day}}-I_{\mathrm{a}}-S\right)}$

Where, $Q_{\text {surf }}$ refers to the accumulated runoff or rainfall excess $(\mathrm{mm}), R_{\mathrm{day}}$ is the rainfall depth for the specific day $(\mathrm{mm}), I_{\mathrm{a}}$ is the initial abstractions, which includes surfacewater storage, interception and infiltration prior to runoff $(\mathrm{mm})$ and $S$ indicates the retention parameter $(\mathrm{mm})$. Equation (2) indicates that the runoff will only occur when the $R_{\text {day }}>I_{\mathrm{a}}$. The changing soils, land use practices, management regimes and slope, will temporally result in the varying of the $S$-value, because of changes in soil-water content.
The retention parameter can be calculated as follows:

$S=25.4\left(\frac{1000}{C N}-10\right)$

Where, $C N$ refers to the curve number for the day. The initial abstractions, $I_{\mathrm{a}}$ is frequently estimated as $0.2 \mathrm{~S}$ and the equation (2) is rewritten as:

$Q_{\text {surf }}=\frac{\left(R_{\text {day }}-0.2 S\right)^{2}}{\left(R_{\text {day }}+0.8 S\right)}$

\subsection{Model inputs}

\subsubsection{Topography and river network}

The morphological dataset used for watershed delineations, discretization, delineated drainage network. The DEM was produced by Vietnam Resources and Environment Corporation in 2009 employing Aerial Photogrammetry technology from the Intergraph Corporation, USA.

\subsubsection{Land use and land cover (LULC)}

Different LULC maps of the study site were prepared using Landsat TM imagery acquired on $28^{\text {th }}$ January 2002 and $30^{\text {th }}$ September 2009 for testing the impacts of land use changes on surface runoff and SY. The ground control points and ground-truth data were extracted from the Yen Bai geodatabase for geometric corrections and the supervised maximum likelihood classified method, respectively.

Table 1. LULC classification accuracy assessment

\begin{tabular}{|c|c|c|c|c|c|c|c|c|c|c|c|}
\hline $\begin{array}{l}\text { LULC } \\
\text { (year) }\end{array}$ & $\begin{array}{l}\mathbf{P} / \mathbf{U} \\
(\%)\end{array}$ & Forest & Lake & River & Urban & Agriculture & Shrubland & Grassland & Barren & $\begin{array}{l}\mathbf{O} \\
(\%) \\
\end{array}$ & Kappa \\
\hline \multirow{3}{*}{2002} & $\mathrm{P}$ & 78.0 & 82.4 & 57.5 & 73.6 & 61.1 & 61.8 & 61.5 & 76.2 & \multirow{3}{*}{69.3} & \multirow{3}{*}{0.648} \\
\hline & & & & & & & & & & & \\
\hline & $\mathrm{U}$ & 72.1 & 73.9 & 61.1 & 73.3 & 65.6 & 65.0 & 63.7 & 77.2 & & \\
\hline \multirow[b]{2}{*}{2009} & $\mathrm{P}$ & 86.2 & 88.8 & 76.3 & 72.3 & 73.4 & 73.8 & 64.0 & 74.7 & \multirow[b]{2}{*}{76.8} & \multirow[b]{2}{*}{0.734} \\
\hline & & 865 & 7 & 747 & 750 & 60 & 72 & 727 & 707 & & \\
\hline
\end{tabular}

$\mathrm{P}=$ Producer accuracy, $\mathrm{U}=$ User accuracy, $\mathrm{O}=$ Overall accuracy, and Kappa is the kappa statistic or kappa coefficient.

The LULC was classified into nine classes for each map as shown on the Figure 2. The Kappa statistics (Berry, 1992) producer accuracy and user accuracy were assessed for each class of the maps and written in Table 1. The average Kappa statistic of 0.7 was calculated and asserted a substantial agreement based on Viera \& Garrett (2005).

\subsubsection{Soils}

The Yen Bai custom soil (YBS) map below generated in the MapInfo software in 1996 and set by the FAO/UNESCO norms for quality. Fifteen soil types were classified with their characteristics such as gradient (4 level of $0-8^{\circ}, 8^{\circ}-15^{\circ}, 15^{\circ}-25^{\circ}$ and above $25^{\circ}$ ), soil thicknesses, soil texture, profiles etc. and divided into 6 major soil groupings including fluvisols, calcisols, ferralsols, alisols, acrisols and gleysols. The two dominant soils are Plinthic Ferralsols and Gleyic Alisols with distribution of 3855.8 and $998.6 \mathrm{~km}^{2}$, respectively.

Secondly, the FAO Digitized Soil (FAO soils) Map of the World, version 3.6, was completed January 2003. Based on the FAO soils, only the two soil types are identified in the study region namely Ferric Acrisols and Orthic Acrisols. 


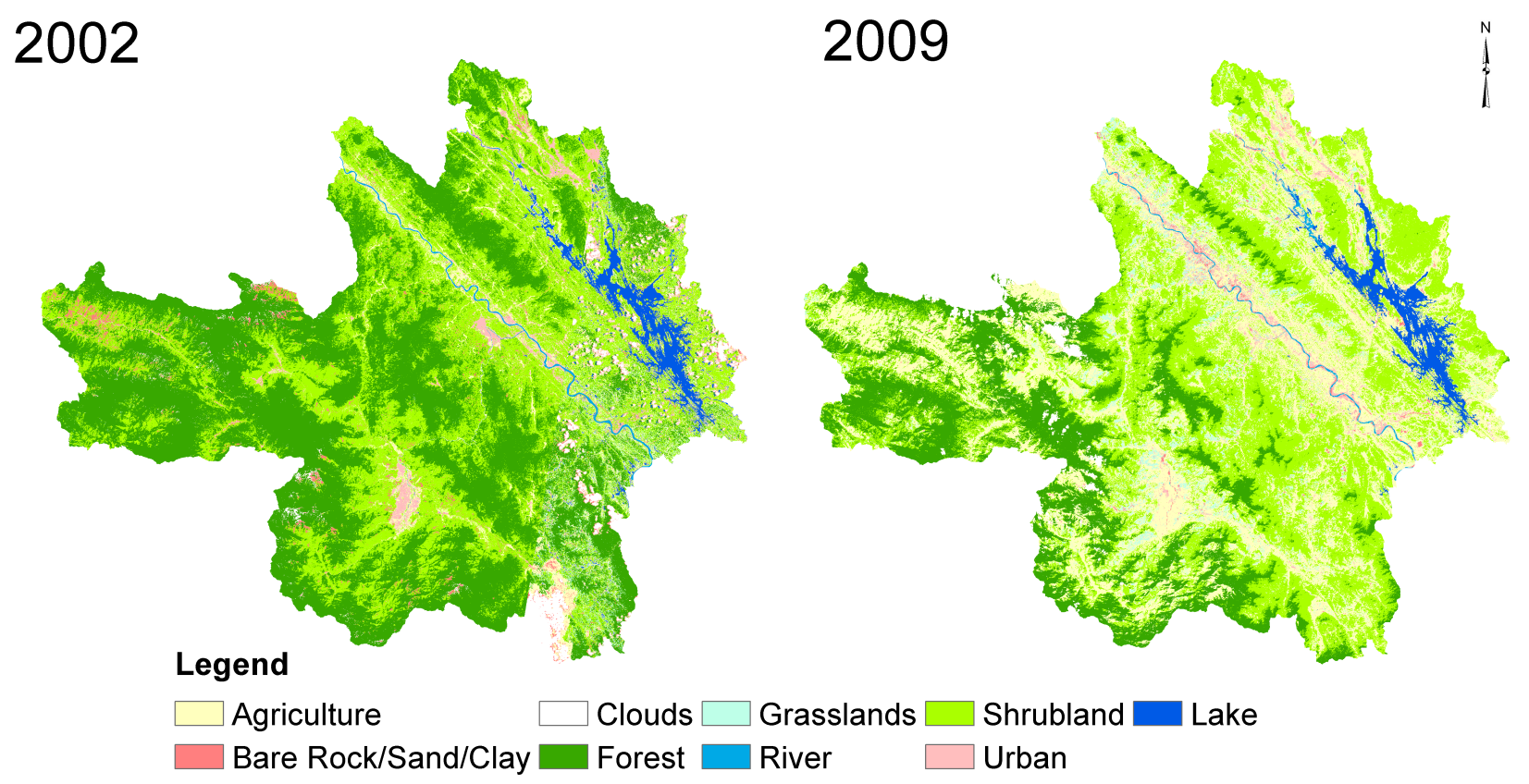

Figure 2. Maps of LULC mapped from Lansat TM scenes for Yen Bai province

\subsubsection{Precipitation and temperature}

Point measurements of daily rainfall and temperature were recorded by nine gauges (see Fig. 1) conducted inside the province and surroundings. The twelve-year daily data (from 01.01.2001 to 31.12.2012) was acquired and processed in Excel environment in order to generate the precipitation and temperature inputs for the SWAT model. Some short missing data was interpolated using the inverse-distance weighted equation (Shepard, 1986). Distributed data of precipitation and temperature were generated from gauged data using the Thiessen polygon method (Thiessen, 1911).
Model calibration was done manually "by changing sensitive parameters" employing 5-year gauged data (daily and monthly) from 2001 to 2005 . Some model sensitive parameters such as the $\mathrm{CN}$, base flow recession and soil evaporation compensation were adjusted at this stage. Both the model calibration and validation (7-year periods of 20062012) were done for the Nam Kim and Ngoi Hut watersheds and the top-ten sensitive parameters are tabularised in the Table 2 . The model performance was investigated by using the coefficient of determination $\left(R^{2}\right)$, Nash-Sutcliffe coefficient of simulation efficiency (NSE) (Nash \& Sutcliffe, 1970) values.

\subsection{Model calibration, validation and simulation}

Table 2. SWAT initial and final calibrate parameters (NK = Nam Kim, NH =Ngoi Hut)

\begin{tabular}{|c|c|c|c|c|c|c|}
\hline Parameter & Description & Unit & Range & $\begin{array}{l}\text { Initial } \\
\text { value }\end{array}$ & $\begin{array}{l}\text { Final } \\
\text { value } \\
(\mathrm{NK})\end{array}$ & $\begin{array}{l}\text { Final } \\
\text { value } \\
(\mathrm{NH})\end{array}$ \\
\hline $\mathrm{CN} 2$ & Curve number condition 2 & - & $35-98$ & 35 & 54.1 & 48.7 \\
\hline Alpha_Bf & Baseflow recession constant & days & $0-1$ & 0.04 & 0.4 & 0.5 \\
\hline $\mathrm{Ch} \mathrm{K}_{\overline{2}}$ & $\begin{array}{l}\text { Effective hydraulic conductivity in } \\
\text { channel }\end{array}$ & $\mathrm{mm} \mathrm{hr}^{-1}$ & $-0.01-500$ & 50 & 75 & 50 \\
\hline Sol_K & Saturated hydraulic conductivity & $\mathrm{mm} \mathrm{hr}^{-1}$ & $0-2000$ & 2 & 4.30 & 16.03 \\
\hline $\mathrm{Ch} \_\mathrm{N} 2$ & Manning $n$ value for the main channel & - & $-0.01-0.3$ & 0.015 & 0.05 & 0.05 \\
\hline Surlag & Surface runoff lag coefficient & - & $1-24$ & 4 & 2.5 & 5.6 \\
\hline Sol_Awc & Available water capacity & $\begin{array}{c}\mathrm{mm} \\
\mathrm{mm}^{-1}\end{array}$ & $0-1$ & 0.22 & 0.31 & 0.35 \\
\hline Gw_Revap & Revap coefficient & - & $0.02-0.2$ & 0.02 & 0.2 & 0.2 \\
\hline Esco & Soil evaporation compensation factor & - & $0-1$ & 0 & 0.95 & 0.95 \\
\hline Gwqmin & $\begin{array}{l}\text { Threshold water level in shallow aquifer } \\
\text { for base flow }\end{array}$ & $\mathrm{Mm}$ & $0-5000$ & 0 & 1500 & 2000 \\
\hline
\end{tabular}

\section{Results and discussion}

\subsection{Monthly surface runoff}

Figure 3 presents the 5 -year results of the model calibration of monthly outflow from 2001 to 2005 . Before model calibration (Figs $3 \mathrm{a}$ and $\mathrm{b}$ ), basically there were underestimates of base flows and the peaks for both the Nam Kim $\left(\mathrm{NSE}=0.3, R^{2}=0.81\right)$ and Ngoi Hut $\left(\mathrm{NSE}=0.1, R^{2}=0.39\right)$. 
On the other hand, the model performed excellently with the calibrated discharge matching closely with the measured data for both the watersheds, verified by evaluating NSE of $0.86, R^{2}=0.87$ for the Nam Kim and NSE of 0.81 ,
$R^{2}=0.76$ for the Ngoi Hut (Figs. $3 \mathrm{c}$ and d), respectively. It was a result of alternation of the base flow recession, inter flow and other parameters.

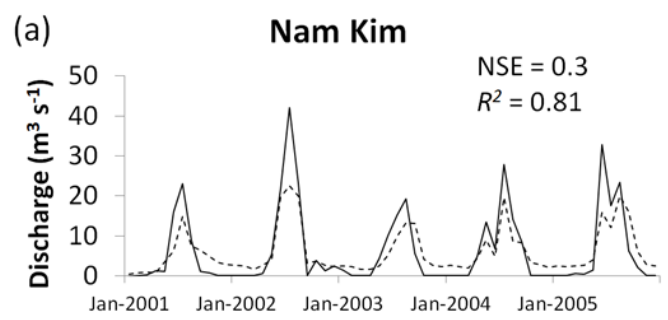

(c)
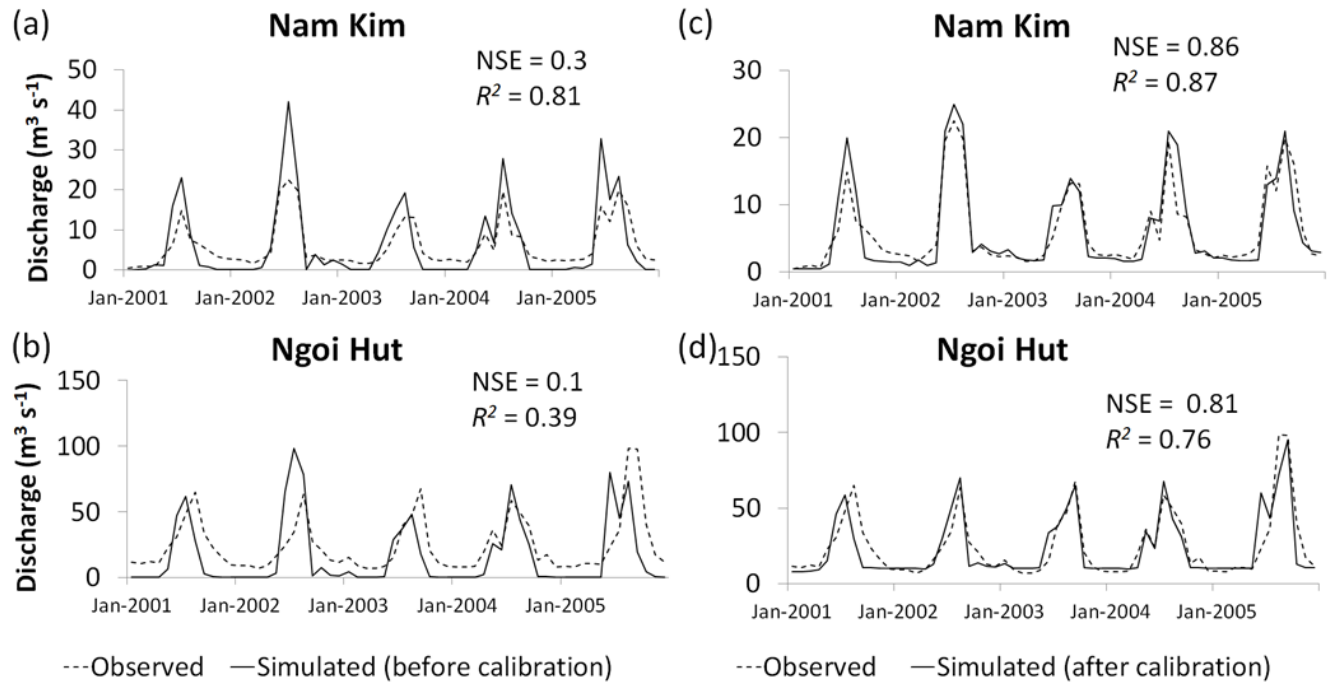

Figure 3. Observed and simulated monthly surface runoff before calibration (a and b) and after calibration (c and d)

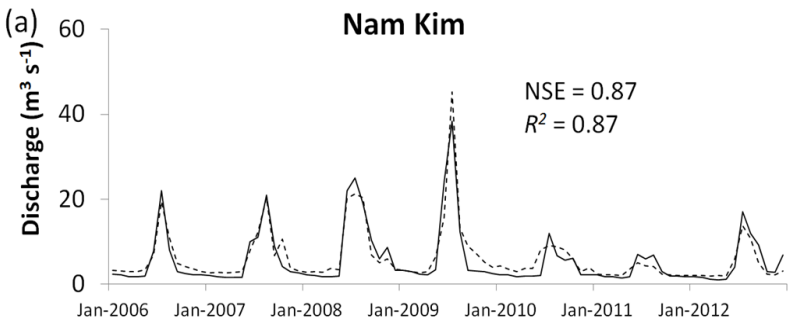

2010 to 2011 in the Nam Kim and from 2009 to 2010 in the Ngoi Hut.

\subsection{Relationships between annual precipitation, simulated surface runoff and sediment yield}

In general, there were significant positive correlations between annual rainfall, surface runoff and SY in the three basins (Fig. 5) calculated for the 2001-2012 period indi-

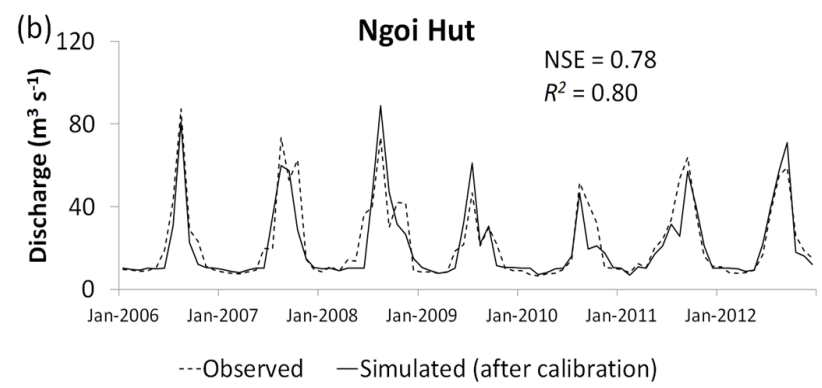

Figure 4. Observed and simulated monthly surface runoff for model validation (a) the Nam Kim (b) the Ngoi Hut

The good model results of monthly validation during the 7 years from 2006 to 2012 were illustrated on Figure 4 for the Nam Kim and Ngoi Hut. Based on the NSE and $R^{2}$ values, the model performed better with the smaller watershed (the Nam Kim-Fig. 4a with both the NSE and $R^{2}$ of 0.87 ) compared to the bigger one of the Ngoi Hut (Fig. $4 \mathrm{~b}$ with NSE of $0.78, R^{2}$ of 0.8 ). The figure also showed variations of runoff in rainy and dry seasons in quite big ranges of about 40 and $80 \mathrm{~m}^{3} \mathrm{~s}^{-1}$ for the Nam Kim and Ngoi Hut and the very consistent time of peaks in July (also in the calibration period). The two-year driest periods were from were larger than 0.65 (particularly 0.91 for the relationship between runoff and SY in the Hong basin). These results might reveal that the model estimates were possibly reasonable.

The figure also shows the simulated surface runoff and SY values for the three basins. Although the Chay had the highest annual mean precipitation (AMP) of $1800 \mathrm{~mm}$, the average runoff $(43 \mathrm{~mm})$ and SY $\left(1.7 \mathrm{t} \mathrm{ha}^{-1} \mathrm{y}^{-1}\right)$ were not much higher than in the Hong basin (mean runoff of 36 $(\mathrm{mm})$ and SY of $1.5 \mathrm{t} \mathrm{ha}^{-1} \mathrm{y}^{-1}$ ) with AMP of around 1400 $(\mathrm{mm})$. The Da basin presented the most eroded area with an annual mean rate of over $4\left(\mathrm{tha}^{-1} \mathrm{y}^{-1}\right)$ and runoff of 60 ( $\mathrm{mm}$ ) but the AMP was $100 \mathrm{~mm}$ less than in the Chay. The high SR and SY rates of the Da could be explained by a positive proportional linkage between slopes and SR and SY values (Oliveira et al., 2013).

Figure 5 also indicates that in some wet years (AMP $>1800$ $\mathrm{mm})$ both the runoff and SY rates were higher than 60 $(\mathrm{mm})$ and $5\left(\mathrm{t} \mathrm{ha}^{-1} \mathrm{y}^{-1}\right)$, respectively and particularly in the Da basin. On the other hand, in some dry years when the runoff rates were estimated less than $20(\mathrm{~mm})$, the SY values were nearly zero. That proved the changes in runoff and SY over the years were significant. 

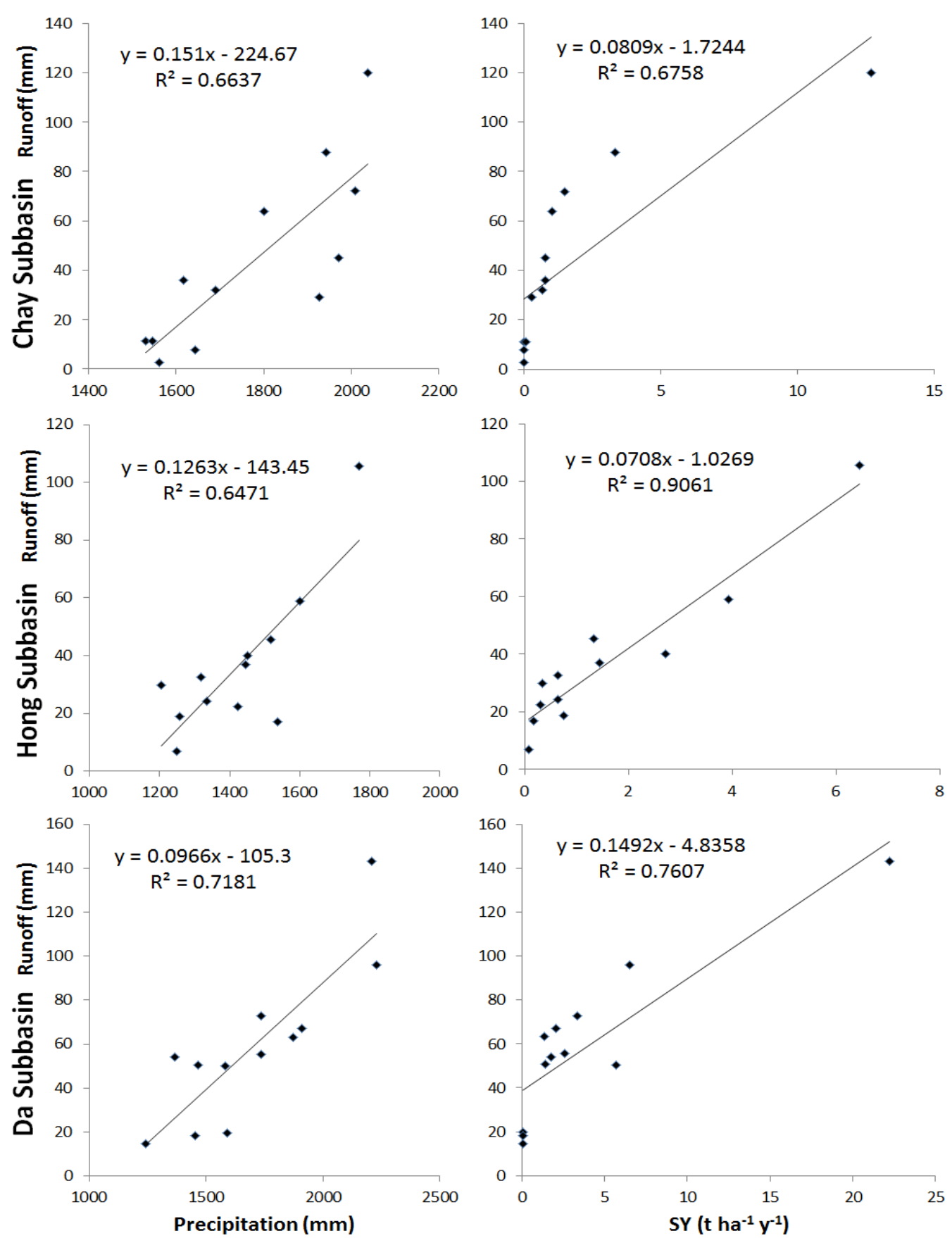

Figure 5. Correlations between annual rainfall, simulated surface runoff and sediment yield

\subsection{Estimated soil loss for Yen Bai province comparing with data from the Atlas of Vietnam, 1997}

Figure 6 shows estimated annual mean soil erosion rates (12-year) using different LULC and soil data compared with soil erosion map extracted from the VN-Atlas, 1997. The significant soil erosion areas were in $\mathrm{Mu}$ Cang Chai and Tram Tau districts and the moderate erosive areas were in the remaining districts in all cases. The maps also indicated the changes of land use (Figs $6 a$ and $b$ ) effect on the soil erosion patterns. Some noted increases can be seen in the Mu Cang Chai, Van Yen and Van Chan districts with the dark-blue colours. The use of FAO soils (Fig. 6d) produced the coarse maps or some areas could be combined into one zone. On the other hand, the employment of the YBSs generated finer maps and is recommended to be used for provincial scale. Intuitively, the soil loss distributions shown on the map correlated well with the coarse map of the VN-Atlas, 1997 (Fig. 6c) even if they were in different scales. 


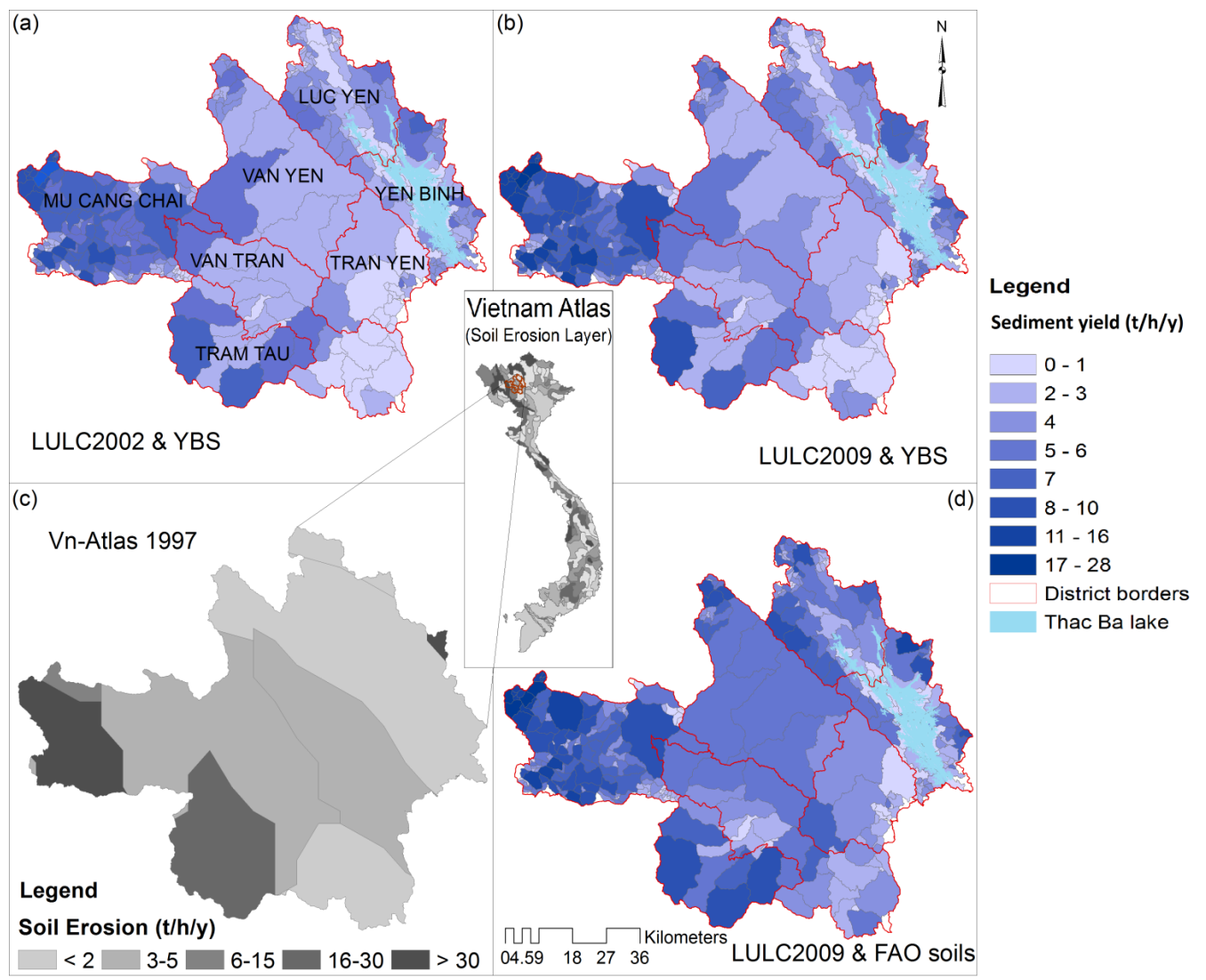

Figure 6. Observed and simulated monthly surface runoff for model validation (a) the Nam Kim (b) the Ngoi Hut

\subsection{Land use changes effect on soil erosion distributions}

One of the important assessments of this study is to evaluate to what extent the changes in LULC affect the annual mean soil erosion values. The results (Fig. 7) illustrated that reduction of the vegetative cover increased soil erosion rates and most of the red areas (increased from one to $3.3 \mathrm{t}$ $\mathrm{ha}^{-1} \mathrm{y}^{-1}$ ) were the results of vegetation reductions and the increase in available agricultural land (compared with Fig. 2). Conversely, some areas were well protected by vegetative cover (in blue and light blue), possibly due to afforestation and decline in bare land.

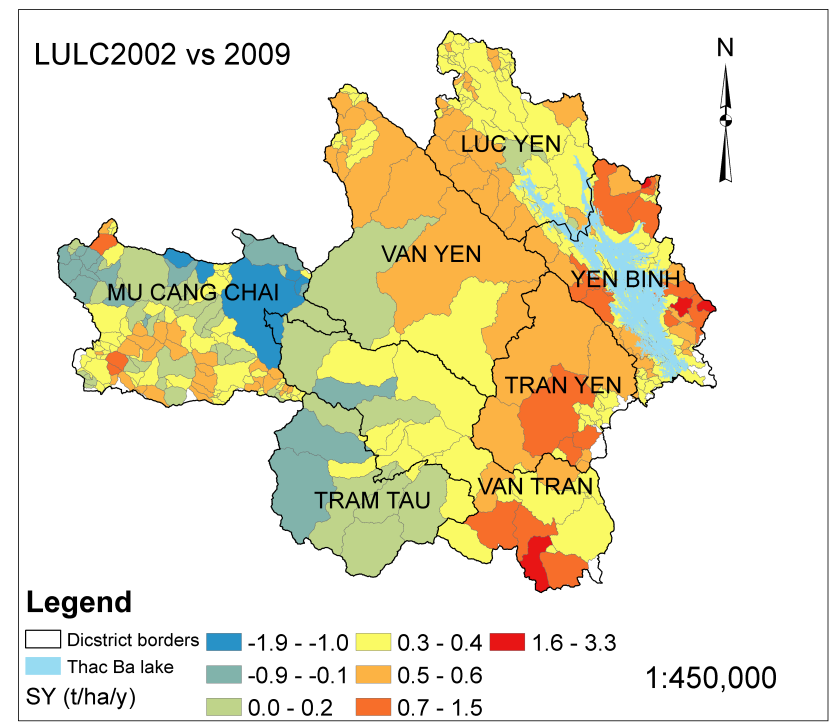

Figure 7. Map of soil erosion changes based on LULC2002 and 2009 conditions

\section{Discussion and conclusion}

At the model pre-calibration, the model underestimated the base flow and overestimated the peaks as well. A possible explanation for this might be that the model was originally developed for arid regions with low in flow and low soil moisture but computed for the tropics. However, the results of 5-year calibration and 7-year validation revealed that the monthly and daily simulated runoff matched closely with the measured discharge. This might indicate the flexibility of the model and that it could be adopted for the tropics in respect of surface runoff estimates. The study results could be archived better, if the input climate data were recorded for 20 years (Neitsch et al., 2009) or longer. For this remote-developing study site, the use of 12-year climatic data is acceptable but longer time-series climatic data is still needed for better accurate WSE estimation. In addition, the observed SY data is not available in the study site. Therefore, there is a need for in situ observations of model validation.

Beside the climatic and topographic aspects, the LULC plays an important role in shaping the soil erosion distributions. The reason for the increase of SY shown on the maps (Fig. 7) could be a reduction of vegetative cover during 2002 to 2009 . This vegetative cover decrease led to higher estimated soil loss rates and this finding is in agreement with the findings of Baja et al. (2009) and Bakimchandra (2011). The increase in WSE rates might cause an increase in agricultural land and bare land, especially in the uplands (Abaci and Papanicolaou, 2009) of the region as well. As this role is significant, seasonal effects on LULC classification have to be taken in to account for classification accuracy and later on resulted in evaluating WSE (Karambiri 
et al., 2003 and Kefi et al., 2011). In the tropics, such as in the north of Vietnam, the agricultural land is cultivated very intensively, three or even more crops per year. This makes different reflectance on satellite scenes with different kinds of crops and, thus, sufficient ground-truth data (number of samples and being representative) has to be derived for the agricultural class. In addition, the annual soil erosion map derived from the Vn-Atlas, 1997 was assumingly not fine enough but it could somewhat verify the model's results. Remarkably, with the same inputs of the larger scale FAO soil map the model estimated a slightly higher SY rate. This was possibly due to a disappearance of water bodies in the map and in these areas the deposition processes are often more dominant rather than the erosive stages (Butt et al., 2010 and Schmengler, 2010).

An important finding is that the close linkages between annual rainfall, SR and SY were investigated for the 2001-2012 period and shown by the scattered graphs and equations. The equations and the $R^{2}$ values explained the logically good correlation between these factors. Surprisingly, the Da basin was found to be the most eroded area with precipitation lower than in the Chay. This rather contradictory result may be due to the strong linkage between slope, runoff and SY (the Da has the highest slope length and gradient). This relationship can also easily be seen in the equations 1 and 2 and explained more in Neitsch et al. (2009).

Generally, the positive proportional linkages between AMP, SR and SY were found from those simulated results for the three basins. Significantly, soil erosion rates were estimated by the model and summarized and mapped with a consideration of LULC changes. Although the on-site SY measurement was not available for model validation, equivalent rates and distribution between simulated and existing map data have been presented. From all these, the SWAT model provides an effective tool to estimate SR and WSE for tropical regions.

\section{Acknowledgements}

We thank the Vietnam National Centre for Hydro-Meteorological Forecasting and the Vietnam Natural Resources and Environment Corporation for providing meteorological and topographical data for this research.

\section{References}

[1] Abaci, O., \& Papanicolaou, A. N. T., 2009. Longterm effects of management practices on water-driven soil erosion in an intense agricultural sub-watershed: monitoring and modelling. Hydrological Processes, 23(19), 2818-2837. doi: Doi 10.1002/Hyp.738

[2] Ananda, J., \& Herath, G., 2003. Soil erosion in developing countries: a socio-economic appraisal. Journal of Environmental Management 68, 343-353.

[3] Andrade, O., Kappas, M., \& Erasmi, S., 2010. Assemment of Erosion Hazard in Torres Municipality of Lara State (Venezuela) based on GIS. Asociación Interciencia Venezuela, Interciencia, Vol. 35, Núm. 5, mayo-sin mes, 2010, pp. 348-356.
[4] Arnhold, S., Lindner, S., Lee, B., Martin, E., Kettering, J., Nguyen, T. T., . . . Huwe, B., 2014. Conventional and organic farming: Soil erosion and conservation potential for row crop cultivation. Geoderma, 219-220(0), 89-105. doi: http://dx.doi.org/10.1016/j.geoderma.2013.12.023

[5] Baja, S., Ramli, M., \& Lias, S. A., 2009. Spatialbased assessment of land use, soil erosion, and water protection in the Jeneberang valley, Indonesia. Biologia, 64(3), 522-526. doi: DOI 10.2478/s11756-0090074-y

[6] Bakimchandra, O., 2011. Integrated Fuzzy-GIS approach for assessing regional soil erosion risks. $\mathrm{PhD}$ thesis.

[7] Berry, C. C., 1992. The kappa statistic. Journal of the American Medical Association, 268(18):2513.

[8] Butt, M. J., Waqas, A., Mahmood, R., \& Cshrg., 2010. The Combined Effect of Vegetation and Soil Erosion in the Water Resource Management. Water Resources Management, 24(13), 3701-3714. doi: DOI 10.1007/s11269-010-9627-7

[9] David, M., Follain, S., Ciampalini, R., Le Bissonnais, Y., Couturier, A., \& Walter, C., 2014. Simulation of medium-term soil redistributions for different land use and landscape design scenarios within a vineyard landscape in Mediterranean France. Geomorphology, 214(0), 10-21. doi: http://dx.doi.org/10.1016/j.geomorph.2014.03.016

[10] De Munck, C. S., Hutchings, T. R., \& Moffat, A. J., 2008. Impacts of climate change and establishing a vegetation cover on water erosion of contaminated spoils for two contrasting United Kingdom regional climates: a case study approach. Integr Environ Assess Manag, 4(4), 443-455. doi: 10.1897/IEAM_2008-016.1

[11] Dercon, G., Mabit, L., Hancock, G., Nguyen, M. L., Dornhofer, P., Bacchi, O. O. S., . . Zhang, X., 2012. Fallout radionuclide-based techniques for assessing the impact of soil conservation measures on erosion control and soil quality: an overview of the main lessons learnt under an FAO/IAEA Coordinated Research Project. Journal of environmental radioactivity, 107(0), 78-85. doi: 10.1016/j.jenvrad.2012.01.008

[12] Evans, R., 2005. Monitoring water erosion in lowland England and Wales - A personal view of its history and outcomes. CATENA, 64(2-3), 142-161. doi: DOI 10.1016/j.catena.2005.08.003

[13] Fukunaga, D. C., Cecílio, R. A., Zanetti, S. S., Oliveira, L. T., \& Caiado, M. A. C., 2015. Application of the SWAT hydrologic model to a tropical watershed at Brazil. CATENA, 125(0), 206-213. doi: http://dx.doi.org/10.1016/j.catena.2014.10.032

[14] Green, W. H., \& Ampt, G. A., 1911. Studies on soil physics, 1 . The flow of air and water through soils. Journal of Agricultural Sciences 4:11-24.

[15] Gumiere, S. J., Raclot, D., Cheviron, B., Davy, G., Louchart, X., Fabre, J. C., Le Bissonnais, Y., 2011. MHYDAS-Erosion: a distributed single-storm water 
erosion model for agricultural catchments. Hydrological Processes, 25(11), 1717-1728. doi: Doi 10.1002/Hyp.7931

[16] Karambiri, H., Ribolzi, O., Delhoume, J. P., Ducloux, J., Coudrain-Ribstein, A., \& Casenave, A., 2003. Importance of soil surface characteristics on water erosion in a small grazed Sahelian catchment. Hydrological Processes, 17(8), 1495-1507. doi: Doi 10.1002/Hyp. 1195

[17] Kefi, M., Yoshino, K., Setiawan, Y., Zayani, K., \& Boufaroua, M., 2011. Assessment of the effects of vegetation on soil erosion risk by water: a case of study of the Batta watershed in Tunisia. Environmental Earth Sciences, 64(3), 707-719. doi: DOI $10.1007 / \mathrm{s} 12665-010-0891-\mathrm{x}$

[18] Lopez-Vicente, M., Poesen, J., Navas, A., \& Gaspar, L., 2013. Predicting runoff and sediment connectivity and soil erosion by water for different land use scenarios in the Spanish Pre-Pyrenees. CATENA, 102, 62-73. doi: DOI 10.1016/j.catena.2011.01.001

[19] Mukundan, R., Pradhanang, S. M., Schneiderman, E. M., Pierson, D. C., Anandhi, A., Zion, M. S., Steenhuis, T. S., 2013. Suspended sediment source areas and future climate impact on soil erosion and sediment yield in a New York City water supply watershed, USA. Geomorphology, 183, 110-119. doi: DOI 10.1016/j.geomorph.2012.06.021

[20] Nash, J. E., \& Sutcliffe, J. V., 1970. River flow forecasting through conceptual models 1 : a discussion of principles. Journal of Hydrology 10 (3), 282-290.

[21] Neitsch, S. L., J.G. Arnold, J.R. Kiniry , \& Williams, J. R., 2009. Soil and Water Assessment Tool Theoretical Documentation, Version 2009. Texas Water Resources Institute Technical Report No. 406.

[22] Oliveira, A. H., Silva, M. L. N., Curi, N., Avanzi, J. C., Neto, G. K., \& Araujo, E. F., 2013. Water Erosion in Soils under Eucalyptus Forest as Affected by Development Stages and Management Systems. Ciencia E Agrotecnologia, 37(2), 159-169.

[23] Routschek, A., Schmidt, J., Enke, W., \& Deutschlaender, T., 2014. Future soil erosion risk - Results of GIS-based model simulations for a catchment in Saxony/Germany. Geomorphology, 206(0), 299-306. doi: morph.2013.09.033

[24] Schmengler, A. C., 2010. Modeling soil erosion and reservoir sedimentation at hill and catchment scale in semi-arid Burkina Faso. PhD thesis.

[25] Shepard, D., 1986. A two-dimensional interpolation function for irregularly spaced data. In Proceedings of the 1968 23rd ACM National Conference, 517-523.
[26] Thiessen, A. H., 1911. PRECIPITATION AVERAGES FOR LARGE AREAS. Monthly Weather Review, 39(7), 1082-1089. doi: $10.1175 / 1520-$ 0493(1911)39<1082b:PAFLA > 2.0.CO;2

[27] Tibebe, D. B., W., 2011. Surface Runoff and Soil Erosion Estimation Using the Swat Model in the Keleta Watershed, Ethiopia. Land Degradation \& Development, 22(6), 551-564. doi: Doi 10.1002/Ldr.1034

[28] USDA-SCS., 1972. USDA Soil Conservation Service-National Engineering Handbook Section 4. Hydrology and, Chapters 4-10.

[29] USDA-SCS., 1986. Technical Release 55, Urban hydrology for small watersheds. United States Department of Agriculture, Soil Conservation Service, http://www.wcc.nrcs.usda.gov/hydro//hydro-toolsmodels-tr55.html.(Chapter 9 and 10).

[30] VEM, V. E. M., 2012. Chính sách đất đai phát triển "tam nông": Những vấn đề đặt ra. http://www.tapchitaichinh.vn/Trao-doi-Binh-luan/Chinh-sach-dat-daiphat-trien-tam-nong-Nhung-van-de-datra/14637.tctc. (assessed on $7^{\text {th }}$ November 2014).

[31] Vn-Atlas., 1997. Atlas of national physical maps of 66 fields. Viet Nam Publishing House of Natural Resources, Environment and Cartography, 1997. http://www.bando.com.vn/en/default.aspx

[32] Viera, A. J., \& Garrett, J. M., 2005. Understanding Interobserver Agreement: The Kappa Statistic. Family Medicine, Fam Med 2005;37(5):360-3.

[33] Williams, J. R., 1975. Sediment-yield prediction with universal equation using runoff energy factor. p. 244252, In Present and prospective technology for predicting sediment yield and sources: Proceedings of the sediment-yield workshop, USDA Sedimentation Lab., Oxford, MS, November 28-30, 1972. ARS-S40.

[34] Williams, J. R., 1995. Chapter 25: The EPIC model. p. 909-1000. In V.P. Singh (ed.) Computer models of watershed hydrology. Water Resources Publications.

[35] Wischmeier, W. H., \& Smith, D. D., 1965. Predicting rainfall-erosion losses from cropland east of the Rocky Mountains. Agriculture Handbook 282. USDA-ARS.

[36] Wischmeier, W. H., \& Smith, D. D., 1978. Predicting rainfall erosion losses: a guide to conservation planning. Agriculture Handbook 282. USDA-ARS.

[37] Zhang X., R. Srinivasan, \& Liew, M. V., 2008. Multisite Calibration of the SWAT Model for Hydrological Modelling. 